INSECTS AS HUN FOOD: AN OVER 


\section{INSECTS AS HUMAN FOOD: AN OVERVIEW}

ERALDO MEDEIROS COSTA NETO

UNIVERSIDADE ESTADUAL DE FEIRA DE SANTANA, BRASIL 


\title{
INSECTS AS HUMAN FOOD: AN OVERVIEW
}

\begin{abstract}
Although insects and the products elaborated and/or eliminated by them are used as food source by three thousand traditional societies in over 120 countries, current attitudes of repugnance regarding the consumption of edible insects cause that a considerable amount of animal protein becomes unavailable to those individuals who suffer from protein deficiencies. Considering the nutritional qualities that insects have, they should be considered as renewable resources available for sustainable exploitation aiming at reducing the problem of malnutrition and hunger in many parts of the world.
\end{abstract}

Keywords: Entomophagy, food safety, renewable resources, culture, insects.

\section{INSETOS COMO ALIMENTO HUMANO: UMA REVISÃO GERAL}

\section{Resumo}

Embora os insetos e os produtos elaborados e/ou eliminados por eles sejam usados como fonte de alimento por três mil grupos étnicos em mais de 120 países, as atitudes comuns de repugnância direcionadas ao consumo de insetos comestíveis levam a que uma quantidade considerável de proteína animal fique indisponível para aqueles indivíduos que sofrem de deficiências proteicas. Observando as qualidades nutricionais que os insetos possuem, eles deveriam ser considerados como recursos renováveis disponíveis para exploração sustentável, assim diminuindo o problema de desnutrição e fome em muitas partes do mundo.

Palavras-chave: Entomofagia, segurança alimentar, recursos renováveis, cultura, insetos. 


\section{INSECTOS COMO ALIMENTO HUMANO: UNA VISIÓN GENERAL}

\section{Resumen}

Aunque los insectos y los productos elaborados y/o eliminados por ellos sean utilizados como fuente de alimento por tres mil grupos étnicos en más de 120 países, las actitudes comunes de repugnancia hacía al consumo de insectos comestibles provoca que una cantidad considerable de proteína animal esté indisponible para aquellos individuos que sufren de deficiencias proteicas. Observándose las cualidades nutricionales que los insectos poseen, se debería considerarlos como recursos renovables disponibles para exploración sostenida, así disminuyendo el problema de mala nutrición y el hambre en muchas partes del mundo.

Palabras-clave: Entomofagia, seguridad alimentaria, recursos renovables, cultura, insectos.

Endereço do autor para correspondência: Departamento de Ciências Biológicas, Universidade Estadual de Feira de Santana, avenida Transnordestina, S/N, Bairro: Novo Horizonte, CEP: 44036-900, Feira de Santana, BA, Brasil. E-mail: eraldomcosta@gmail.com 


\section{INTRODUCTION}

Insects have been used as foodstuffs since the dawn of human race. Australopithecus robustus Broom, 1938 used bone tools to dig into termite mounds 500.000 years ago (van der Merwe et al. 2003). There are rock paintings depicting humans collecting honey from beehives that date back to Paleolithic times (Hernández-Pacheco 1921). Even in the Bible there are records of the use of insects as food. The manna was nothing more than the excretion of the mealybug Trabutina mannipara (Hemprich and Ehrenberg 1829) (Homoptera: Pseudococcidae). Females eliminate a sugary liquid that in arid climates dries over leaves and builds up in layers (Buzzi \& Miyazaki 1993). In the Mideast, people still collect the sweet excretion of scale insects that feed on tamarisk (Tamarix mannifera Kotschy ex Bunge). They call it "man" and it is, most likely, the manna describe in the Old Testament (Hölldobler \& Wilson 1994).

Estimates of the number of insect species that are consumed by humans vary, but worldwide at least 1,400 species have been recorded as human food (Durst \& Shono 2010). Depending on species and instar, they are rich in proteins, fats, carbohydrates or salts, providing the consumers with valuable nutrients that are reasonably easy to obtain, usually by selecting the animals in their natural habitat (RamosElorduy et al. 1997, 1998a, 1998b). In fact, most traditionally-living cultures still practice entomophagy, consuming a set of many different species as a dietary supplement, as a replacement of other food in times of shortage, or as the main constituent of the diet. However, insect consumption is widespread since edible species are used by approximately three thousand ethnic groups in 120 countries ( $\mathrm{Ra}$ mos-Elorduy 2000). Almost all taxa are consumed, but some groups only locally. While saturniid caterpillars, beetle grubs, grasshoppers and crickets are popular almost everywhere, adult dragonflies are consumed only in SEAsia and certain salt flies only in the USA (Bristowe 1932; Essig 1934; Bergier 1941; Bodenheimer 1951; Stone 1992; Malaisse 1997; Banjo et al. 2004; DeFoliart 2004; Ramos-Elorduy 2004; Yen 2009b). In some cases, only selected instars of an insect species are consumed, e.g. termite imagos or wasp larvae and pupae. In other taxa, almost all stages are exploited, e.g. juvenile and adult grasshoppers and crickets or ant eggs, larvae, pupae and imagos (DeFoliart 1989).

The degree of entomophagy in a country varies greatly and is influenced by history, tradition and society. In most developing countries, insects are mainly consumed by indigenous sectors of low income, showing that insects, in their present form of usage, represent an economical source for animal protein (Ramos-Elorduy 2011). There are exceptions to this rule, e.g. Mexican ant pupae ("escamole") consumed as delicatessen or an array of insects consumed deep-fried in streets of Thailand (Maheu 2011). 
Insects are also consumed indirectly through ingestion of contaminated food as eggs, feces and even fragments of wings, legs and antennae of cockroaches, bees, ants, crickets and other insects are found. This is due to the impossibility of complete removal of insect parts from food products (Posey 1986). According to Myers (1983), the Food and Drug Administration of U.S.A. (FDA) is acceptable as the encounter of five insects or insect parts to $100 \mathrm{~g}$ of apple butter and 30 insect fragments per $100 \mathrm{~g}$ peanut butter.

They are also eaten through the substances produced by them and used by us as colorants. Today, most culinary dyes have synthetic origin, but in the past the red and pink colors were obtained from insects. The pigment phenoxazine (orange) extracted from Pachilis gigas B. (Hemiptera: Coreidae) showed high dyeing power; it can be used as a colorant to ice creams, cheese, mayonnaise and cream (Perez et al. 1989). The red carmine pigment extracted from Dactylopius coccus Costa, 1835 (Homoptera: Dactylopiidae) is used as a dye for coloring drinks.

Most traditionally-consumed insects may be picked, handled and converted into nutritious foodstuff easily (Johnson 2010). Traditionally, insects are consumed either in a raw state or heated in some fashion. Depending on the culture, heating occurs in hot ashes, toasting devices or by deep-frying them in oil. In dry areas, preservation is done by heating and posterior sundrying; eventually, evisceration was performed before, as in the case of grubs and caterpillars (Ramos-Elorduy et al. 2008). Some works suggested using wild pest species as food, especially grasshoppers (Cerritos \& Cano Santana 2008), while others express their concern regarding insect consumption from the wild (Ramos Elorduy 2006; Yen 2009a). A series of works contemplates the health risks associated with managing insects (Adamolekun et al. 1997; Akinnawo et al. 2002). FAO believes that the specific role of edible insects and their potential in food safety, quality diet and poverty alleviation is severely underestimated (van Huis 2012). Recently, this organization held a meeting on entomophagy in Asia (Durst et al. 2010), showing both diversity and potential of insect consumption across Asia. However, most data focuses on animals captured from the wild. Still, this conference created more awareness in seriously considering entomophagy as a part to solving the food supply problems to come.

For each traditionally-consumed species there is a history of safe use that intends to minimize the consumption risks. Saturniid caterpillars in Western Africa have to be boiled before further processing in order to inactivate the inherent thiaminase; cases of beriberi have been associated to indiscriminate consumption of raw caterpillars. The history of safe use is also important in order to tell inoffensive species from toxic ones (van Huis 2012). In this regard, Blum (1994) discusses on the toxicity of insects eaten by humans, providing several examples of species that should be avoided as food, such as 
cyanogenic species (e.g., butterflies of the families Nymphalidae and Heliconidae), vesicants species (e.g., Lonomia moths), those ones that produce steroids (e.g., Ilybius fenestratus Fabricius, 1781, Dysticidae) and corticosteroids hormones (e.g., Dytiscus marginalis Linnaeus, 1758, Dysticidae), necrotoxic alkaloids (e.g., fire ants Solenopsis spp.) and toluene (e.g., cerambicids of the genus Syllitus). According to this author, the scientific knowledge about the toxic effects of most natural insects is still very scarce. He classifies toxic insects into two groups: cryptotoxic and phanerotoxic species.

Phanerotoxic insects include those that are venomous, presenting a poison apparatus that includes a venom gland, a reservoir, a duct and an apparatus for injecting the venom. Representatives of this group are insects of the orders Lepidoptera (urticating caterpillars), Hymenoptera (ants, wasps, and bees) and Hemiptera (assassin bugs), whose secretions are distributed both by retractable stingers, mouthparts for piercing or stinging arrows. The toxins produced by phanerotoxic species only become active by injection, becoming inactive in the gastrointestinal tract. Nevertheless, some caution is advised.

Cryptotoxic insects are those that produce non-toxic exocrine secretions, whose toxicity is manifested only when they are ingested. These species require more careful in their selection as items to be consumed. Staphylinid beetles of the genus Paederus, for example, produce vesicants which are only detected when they are crushed. One of these is the pederin, a non-protein compound that is a potent inhibitor of protein synthesis and mitosis.

In general, the determinants of the use of insects as a food resource for humans result from four variables: 1) physical environment; 2) availability and accessibility of insects that, in turn, depend on their life cycle, host plants, behavioral adaptations and general ecology; 3) mode of production and subsistence methods of a given culture; 4) dietary restrictions, both nutritionally and temporally (Miller 1997). This author says that an insect is suitable for use as a food source when it is available in large quantities and is easily collected. The importance of a particular animal as a food source for humans is also determined by the efficiency by which this animal converts food that it consumes into its own body weight. The highest weight that is obtained per gram of food ingested corresponds to the more efficient animal in terms of feed conversion (Conconi 1984). Thus, edible insects are highly efficient in this process, only competing with the chicken.

However, insects and other arthropods are still insufficiently investigated by anthropologists and entomologists, being generally regarded as marginal resources in studies on the uses of various available resources. Therefore, it is necessary that researchers conduct studies using an interdisciplinary approach and pay attention to the values and knowledge of traditional people. It is essential to record the rich amount of traditional knowledge, customs, and practices of indigenous and non-in- 
digenous peoples since, with no doubt, they are living representatives of their own culture as well as they have a significant knowledge on the biological resources they depend upon. In this regard, traditional peoples know where, how and when to find edible insect species, and they know different ways to prepare and conserve them in order to have these resources in times of shortage (Ramos-Elorduy 1982).

\section{CULTURAL RESTRICTIONS TO ENTOMOPHAGY}

Entomophagy is not practiced universally. According to Maheu (2011), the greatest obstacles to consumption of insects are cultural and without a deeper understanding of the limitations and possibilities crystallized by culture it will not be possible to promote entomophagy. The idea that we are what we eat is present in all cultures. These beliefs complicate the incorporation of insects in the diet because all associations and assignments related to these arthropods influence our perception of them as food, much more than their nutritional value.

Apparently, Western societies gave it up at Christianization and generally consider this food habit as disgusting, primitive or a sign of poverty. This example is currently followed by those sectors of traditionally entomophagous societies that seek to copy a Western lifestyle; being able to afford meat of domestic animal species is one of the ways to show social and economical progress and to mark a difference to economically weaker parts of their societies (Ramos-Elorduy 2011). In Thailand, a country that has a strong tradition of entomophagy, individuals who have migrated to urban centers and received a formal education "learned" to despise local entomophagous resources when they expose themselves to a cosmopolitan culture that has prejudices against insects (Chen et al. 1998). Moreover, edible insects may serve as a form of national identity as they turn into elements of identification of individuals belonging to the same culture (Ramos-Elorduy 1996). Distaste for the consumption of insects causes that a considerable amount of animal protein becomes unavailable to those people who suffer from hunger and malnutrition.

In Descola's opinion (1998), the habit of eating or not eating insects depends on the variability of individual choice within an accepted norm, as well as the accessibility of the animal. The author complements saying that even within tribal societies there is great variability of individual food preferences and attitudes toward animals. Marvin Harris, a cultural materialistic, explained the repulse on the consumption of insects through a cost/ benefit ratio. He said there are three reasons why a food is to be banned from the menu: when food becomes expensive to be obtained or prepared, when there is more nutritious and inexpensive replacement, or when there is a negative impact on the environment. Over time the food becomes culturally repelled as a food "bad to eat" (Harris 1999). Considering the use of 
insects, he states "the reason we do not eat insects is not because they are dirty and disgusting. Instead, they are dirty and disgusting because we do not eat them."

Different explanations for the consistent human aversion addressed to insects and other invertebrates are available in the literature. One says that humans are biologically predisposed or prepared to fear certain animals, like snakes, scorpions and spiders (Seligman 1971). Another explanation says that common and non-clinical entomophobias may be closely related to the human reaction of "disgust", whose benefits are considered as an adaptive prevention of disease transmission (Davey 1993, 1994; Matchett \& Davey, 1991; Ware et al. 1994). Paul Rozin (1995) shows how foods are primarily classified as pleasant or unpleasant, categories that depend largely on individual variations, sometimes genetic, and secondly as appropriate, inappropriate, disgusting, dangerous, beneficial, categories that are basically determined by culture. The author also shows how some things can be considered edible as well as taboo, and how certain foods are more prestigious than others. Our way of classifying insects and the incorporative beliefs form the basis of a reaction of disgust toward them, so the majority of the population blocks the idea of consuming insects. The aversion involves deep emotions and our own sense of identity in a way that defies any kind of rationalization (Miller 1997; Rozin \& Fallon 1987).

A third interpretation was suggested by the notion of human alienation to creatures as different and distinct from our own species (Kellert 1993). According to this author, more positive attitudes directed at invertebrates are observed when these animals have aesthetic, utilitarian, ecological or recreational values.

Although edible insects have a high nutritional value for humans, they have not been considered a significant source of food and studies on their use as animal feed and waste recycling are still scarce. It is clear that we cannot consume what we do not know about. To introduce insects in the diet, we need to know which species are edible, and how they need to be prepared and cooked for consumption. The fact that knowing about the nutritional and ecological advantages of entomophagy, as well as the consumption of insects by indigenous peoples, can contribute to arise some sympathy among enlightened people, but it will never be enough to eliminate blockages and reinvent the insect as a privileged food where it is initially viewed with despise. To the statements of economic, ecological and nutritional importance of entomophagy to human beings, we also need to take into consideration the very nature of our psycho-cultural limitations (Maheu 2011).

As a measure to increase the nutritional contribution of edible insects, DeFoliart (1989) suggests the following approaches:

- Development of a stronger global defense in order to establish better communication and mutual support among scientists and other interested 
people in the use of insects as food for humans and animal feed.

- More consistent support for scientists from developing countries who are interested in maximizing the nutritional contribution of native species of edible insects.

- Development of methods and economic strategies regarding the mass collection of edible species that are attracted to light or chemical traps.

- Development of controlled mass production of native species of edible insects from developing countries.

- Development of recycling systems using insects to convert organic waste substances and supplements underutilized in feed for poultry, pigs and fish.

- Development of strategies for mass collecting for gregarious destructive pests (e.g. Schistocerca gregaria Forskål, 1775).

- Educating the public on the palatability and nutritive quality of insects, as well as its importance as a food resource for improving the health and life of the various ethnic groups in developing countries.

- Conducting extensive studies on food quality and safety of selected species.
In a society that rejects the consumption of insects there are some individuals who overcome this rejection, but most will continue with this attitude. It will be very difficult to convince an entire society that insects are totally suitable for consumption. In Latin American countries, where insects are already consumed, a portion of the population despises consumption and associates it with poverty and Indianness (Katz 2011). There are also examples of people who have had the habit of consuming them and abandoned that habit due to shame, and because they do not want to be categorized as Indians or poor (Costa Neto 2011). According to Katz (2011), if the consumption of insects as food luxury is to be promoted there would be more chances that some individuals who do not present this habit overcome ideas under which they were educated. And this could also help to revalue the consumption of insects by those people who already eat them.

\section{IN FAVOR OF ENTOMOPHAGY}

Entomophagy has long ceased to be an unstudied phenomenon. Notes on entomophagy were issued the moment non-entomophagous Europeans came into contact with insect-consuming societies. Meanwhile, scientists of many areas studied entomophagy from their specific point of view, e.g. archaeology, anthropology, sociology, and life sciences (Allotey \& Mpuchane 2003; Chakravorty et al. 2011; Mbata et al. 2002; Menzel \& D'Alusio 1998). 
For many species, nutritional data were raised, showing great variation according to species and instar; while protein prevails in many adult instars (imagos), many juvenile instars (maggots, grubs, caterpillars and pupae) also tend to contain elevated levels of fat. Vitamins and mineral content also varies. A Mexican study revealed that in dry matter, grasshoppers may yield up to approx. $80 \%$ of protein, longhorn beetle grubs $60 \%$ of fat and $35 \%$ of fiber, and pierid caterpillars $10 \%$ of ashes (Ramos-Elorduy \& Pino Moreno 1989; rounded values). Nutritional data of many other local species have been gathered, e.g. from Botswana, Nigeria, Zambia, India, Japan, China, and Australia (e.g. Amadi et al. 2005; Banjo et al. 2006; El Hassan et al. 2008; Omotoso 2006). Even data on quality deterioration of processed insects exist (Mpuchane et al. 2000). Corresponding papers usually also include data on the species identification, its life cycle, insect collection and preparation, so a certain data base exists.

Obviously, the chitinous exoskeleton is not digestible by humans (as well as the bark of the apple!), but the exoskeleton is only a small part of the total biomass (about $4 \%$ in caterpillars) and does not affect the nutritional value of insects as food (Berenbaum 1995).

When comparing different feedstuffs and foodstuffs with regard to the protein content (Ramos-Elorduy \& PinoMoreno 1989; Gordon 1998), it becomes clear that insect protein levels usually range above those of most plants, being equal to that other, more commonly used feed and foodstuffs. In the upper segment $(>60 \%)$, the more common feeds and foods are either endangered (tuna and gadiform fish), relatively expensive (pike, crustaceans), unsuitable for non-aquatic livestock feeding (fish meal) or discussed controversially (meat, blood and feather meals), with algae and common mushrooms being the only handy alternatives. However, dry matter in these products is approx. $10 \%$ or lower. Insects usually contain between two and three times more dry matter. In this sense, it seems quite illogical the fact that eating invertebrates such as lobsters, crabs, shrimp, oysters, be considered as part of regular diet, while the consumption of insects, also invertebrates, is viewed with reservations by most people.

As mentioned above, food conversion is an important factor for farmed livestock; to produce one kilogram of meat, 3 to $4 \mathrm{~kg}$ of feed have to be administered to a pig, 4 to 6 to guinea fowls, and 7 to $10 \mathrm{~kg}$ to cattle. In insects, conversion may be close to 1:1 (depending on species and instar), and due the lack of bones, yield of edible tissues is larger. Although some areas were already subjected to research, many others still remain relatively untouched, e.g. the nitrogen use efficiency.

Insects also serve as feed for a great variety of animal species, including domesticated ones and those which are being domesticated (e.g. poultry, pigs, commercial fish species, frogs, ratites and reptiles). Some insect species are reared to satisfy the demand for feed insects by keepers of herpetofauna, fish and birds. Finally, zoos also pro- 
duce insects as a feed additive for the animals they exhibit (DeFoliart 1995; Schickler 2011).

While most research papers deal with traditional (in situ) entomophagy, only some authors issued cookbooks for the Western taste (Gordon 1998; Fritzsche \& Gitsaga 2002) combining insect with known ingredients to a great variety of dishes. These dishes however still contain and display entire insects and might therefore still frighten off phobic consumers. Indeed, people are able to consume insects since these animals are presented in a disguised form. During the First National Symposium on Anthropoentomophagy held at Feira de Santana State University, Brazil, in March 2009, this scenario could be observed. In the workshop of insect cuisine, participants tasted salty and sweet culinary preparations containing some insects (crickets, mealworms, and leaf-cutting ants). During this workshop, "in nature" insects brought greater resistance to consumption, while preparations with crickets (Cantonese stew, pizza, brochette, and cheese rolls) (Figure 1), strawberries with mealworms, and dulce de leche ant canapés (Figure 2) were readily accepted and tasted by all participants. It might be noted also that most people, after consumption, reacted positively to the flavor and texture of the insects, while the look and sociocultural issues were factors of lower receptivity (Linassi \& Borghetti 2011).

Despite the growing number of articles, reviews and books published on the potential of insects as human food, the entomophagous habit remains un-

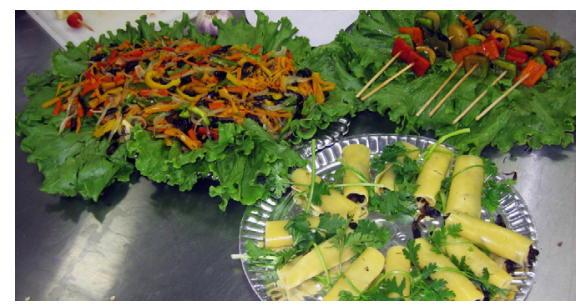

Figure 1 - Cricket-based dishes (Cantonese stew, brochette, and cheese rolls). Photo by Janette Lagunas Raya (2009).

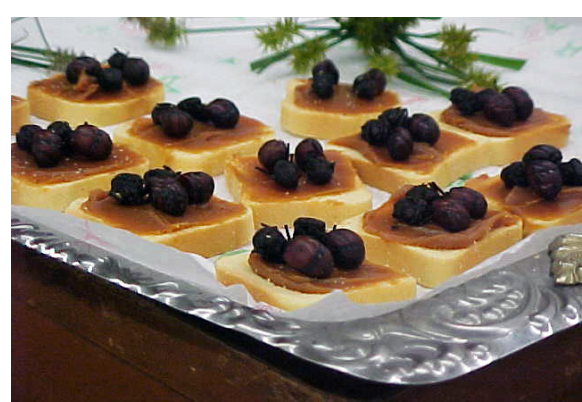

Figure 2-Canapés made of dulce de leche and fried Atta ants. Photo by Gloria Patricia Arango Gutiérrez (2009).

known (or better, despised) since the consumption of insects is taken as a practice of 'primitive people' (Costa Neto 2003, 2004, 2011). It is a disservice to state that insects are eaten only in times of scarcity and famine, as these organisms provide a significant amount of calories and nutrients that are available to people (Ramos-Elorduy 2004).

\section{HYPOTHESIS OF NUTRACEUTICAL ENTOMOFAUNA}

It is known that insects are very prolific in the synthesis of chemical compounds, such as alarm and mating pheromones, defensive sprays, venoms and toxins sequestered from plants or their prey and later concentrated or transformed for their own use (Pemberton 
1999). This huge quantity of chemicals includes compounds that are emetic, vesicant, irritating, cardioactive, or neurotoxic (Berenbaum 1995).

Based on the use of insects as a food source and medicine at the same time, Costa Neto \&Ramos-Elouduy (2006) have postulated the hypothesis of nutraceutical entomofauna. According to this hypothesis, there are many species of insects that are sources of functional foods also provide improvements dually added health by providing services or utility facilities, including prevention and treatment of diseases. The practice of using insects as nutraceuticals occurs in many parts of the world for individuals in a multitude of ethnic groups with different beliefs localized on five continents and employs people of all ages (Ramos-Elorduy 2004; Zimian et al. 2005; Pemberton 2005; Yhoung-Aree \& Viwatpanich 2005). Vegetarians in India, for example, get thaire source of vitamin $B_{12}$ from insects and bacteria that typically contaminate their food (Allport 2000). Many active compounds of nutraceutical insects have been obtained and evaluated pharmacologically (Costa Neto \& Ramos-Elorduy 2006).

Indeed, at the time in which insects were prescribed as therapeutic purposes by healers and practitioners of traditional medicine, people were familiar with the idea of ingestion them (Holt 1988). It is interesting mention that the word medicine owes its origin to the honey, because the first syllable has the same root as mead, an alcoholic drink made from honeycomb that was often consumed as an elixir (Hogue 1987).

\section{WHAT ABOUT BRAZIL?}

Brazil has an extremely rich and lush biosociodiversity, represented both by one of the highest rates of biodiversity on the planet and a vast cultural diversity, as there are currently a total of 222 indigenous ethnic groups recognized by the State (Instituto Socioambiental 2005). In addition to indigenous people, there are several non-indigenous populations such as artisanal fishermen, Amazon 'caboclos' (river-dwellers.), Afro-Brazilian descendents ('quilombolas' communities), and others (Diegues \& Arruda 2001).

Ethnographic data on the practice of entomophagy in Brazil date back to the sixteenth century, when the first chroniclers made the first records about the nature and indigenous peoples. However, the number of species of edible insects in Brazil is undervalued. DeFoliart (2005) only records seven orders, 14 families, 19 genera, and 23 species, while Pereira (1974) records 54 species for the Amazon region. Posey (1987a, 1987b) briefly discusses the cultural and ecological implications of insects as food and summarizes the use of insects for the indigenous peoples of Brazil. Bordotti (2001) made an analysis of literature data published from 1560 to 1999 on the various ways insect diversity is used in Neotropical region, including entomophagy.

Several references provide ample evidence that many insects were (and still are) considered important food for Brazilian indigenous groups. In 2006, Costa Neto \& Ramos-Elorduy published a review on the practice, presenting 
the use of insects as food by 39 indigenous groups (Table 1) and urban communities. A total of 135 types of edible insects have been reported in 14 (54\%) of the 26 states of the Brazilian territory. These resources are divided into nine orders and 23 families. Only 95 are identified to species level while 18 are at the genus level, and some are reported only by their native names. Species belong to the Hymenoptera are the most abundant (63\%), followed by those in the order of Coleoptera with 22 species $(16 \%)$, and Orthoptera with 9 species $(7 \%)$. These resources are consumed as immature (nymphs, larvae and pupae) and as adult, in part or whole, as well as products made by them such as honey, propolis, pollen and wax. In general, people consume edible species depending on their presence, abundance and availability.

With the purpose of exemplifying the use of insect as food resources, it is described below some native uses in the Amazon region. Grasshoppers are important insects in the diet of various indigenous tribes, particularly for the Nhambiquara from the state of Rondônia and the Bakairi from the state of Mato Grosso. For example, both the nymphs (in the rainy season) and adults (in the dry season) of Rhammatocerus schistocercoides (Rehn) are collected by the Nhambiquara, who consume it roasted or as a powder (Embrapa 2000). The Mundurucu people from Pará State used to collect grasshoppers by making holes in the ground and then pushing them to these caves, after that they took away the intestines and consumed them raw or cooked (Santos 1957).

In the northwest Amazon, insects provide approximately 5 to 7 percent of total protein intake during the year. Their contribution increases to 12 to 26 percent during May to June when availability peaks (Dufour 1987). This period coincides with the mature stage of insects. Sutton (1995) studied gender differences in insect consumption and found that men consumed more insects than women, contributing to more than three times the protein intake.

Ribeiro \& Kenhíri (1987) reported the use of seven caterpillars consumed by the Desâna Indians. The local species named as bali' is highly appreciated not only for its excellent flavor, but also because it has a gland that secretes an enzyme that Indians use to remove warts. Larvae can be boiled (after the gland is removed) or prepared by roasting them, then grinding them and then mixing them with salt and dried peppers.

The Tukuna who live in the Amazon basin appreciate the abdomen of red ants (probably Atta sexdens Linnaeus, 1758), which is eaten roasted and mixed with cassava flour. The SateréMaué Indians use to eat a paste made with roasted termites and ants in banana leaves (Lenko \& Papavero 1996).

In a recent ethnoentomological study, Petiza (2011) recorded that the Baniwa Indians living in the town of São Gabriel da Cachoeira, in northwestern Amazon, still use different insect as food resources, such as termites (dáane, keétto, maáki, kanaliére), ants (kaimiri, kadáadali, piite, 
Table 1

Orders of edible insects among the indigenous groups in Brazil. Data from Costa Neto \& Ramos-Elorduy (2006).

\begin{tabular}{|c|c|c|c|c|c|c|c|c|c|}
\hline \multirow{2}{*}{ Ethnicity } & \multicolumn{9}{|c|}{ Orders of edible insects } \\
\hline & ORT & ISO & BLA & ANP & $\mathrm{COL}$ & HOM & HYM & LEP & DIP \\
\hline Amondawa & & & & & & & $\mathrm{x}$ & & \\
\hline Araweté & & & & & $\mathrm{x}$ & & $\mathrm{x}$ & & \\
\hline Ashaninka & & & & & & & $\mathrm{x}$ & & \\
\hline Bakairi & $\mathrm{x}$ & & & & & & & & \\
\hline Bororo & & & & & $\mathrm{x}$ & & & & \\
\hline Botocudo & & & & & & & $\mathrm{x}$ & & \\
\hline Cinta Larga & & & & & $\mathrm{x}$ & & & & \\
\hline \multicolumn{10}{|l|}{ Cocama } \\
\hline Enawenê-Nawê & & $\mathrm{x}$ & & & & & $\mathrm{x}$ & $\mathrm{x}$ & \\
\hline Desâna & $\mathrm{x}$ & $\mathrm{x}$ & & & $\mathrm{x}$ & & $\mathrm{x}$ & $\mathrm{x}$ & \\
\hline Gavião & & & & & $\mathrm{x}$ & & & & \\
\hline Guarani (subgrupo M'byá) & & & & & $\mathrm{x}$ & & $\mathrm{x}$ & & \\
\hline Jamamadi & & & & & & & $\mathrm{x}$ & & \\
\hline Kaingang & & & & & $\mathrm{x}$ & & $\mathrm{x}$ & $\mathrm{x}$ & \\
\hline Kayapó & & $\mathrm{x}$ & & & $\mathrm{x}$ & & $\mathrm{x}$ & & \\
\hline Macu & & $\mathrm{x}$ & & $\mathrm{x}$ & $\mathrm{x}$ & & & $\mathrm{x}$ & \\
\hline \multicolumn{10}{|l|}{ Makuna } \\
\hline \multicolumn{10}{|l|}{ Matis } \\
\hline Mundurucu & $\mathrm{x}$ & $\mathrm{x}$ & & & $\mathrm{x}$ & & $\mathrm{x}$ & $\mathrm{x}$ & \\
\hline Nhambiquara & $\mathrm{x}$ & $\mathrm{x}$ & & & $\mathrm{x}$ & $\mathrm{x}$ & $\mathrm{x}$ & $\mathrm{x}$ & $\mathrm{x}$ \\
\hline \multicolumn{10}{|l|}{ Omágua } \\
\hline Pancararé & & & & & & & $\mathrm{x}$ & & \\
\hline Parakanã & & & & & $\mathrm{x}$ & & $\mathrm{x}$ & & \\
\hline Sateré-Maué & & $\mathrm{x}$ & & & & & $\mathrm{x}$ & & \\
\hline Suruí & & & & & $\mathrm{x}$ & & $\mathrm{x}$ & $\mathrm{x}$ & \\
\hline Tapirapé & & & & $\mathrm{x}$ & & & $\mathrm{x}$ & & \\
\hline Tariano & & & & & & & $\mathrm{x}$ & & \\
\hline Timbira & & & & & $\mathrm{x}$ & & & & \\
\hline Tucano & & & & & $\mathrm{x}$ & & $\mathrm{x}$ & $\mathrm{x}$ & \\
\hline Tukuna & & & & & $\mathrm{x}$ & & $\mathrm{x}$ & & \\
\hline Tupinambá & & & & $\mathrm{x}$ & & & $\mathrm{x}$ & & \\
\hline Tuyuca & & & & & & & $\mathrm{x}$ & & \\
\hline Uru-eu-wau-wau & & & & & & & $\mathrm{x}$ & & \\
\hline
\end{tabular}


Wanana

Xokleng

Xukuru-Kariri

Yanomamo

Yawalapiti

Zoró $\mathrm{x}$

$\mathrm{x}$

$\mathrm{x}$ kóowhenai), beetles (móodi, haliére, déeto), caterpillars (kadaápali), leafhoppers (tsiirito, máami), and crickets (dzíiro).

As Posey (1976) points out, using insects and their products in any quantity presupposes a sophisticated folk knowledge about these organisms and their behavior, which is revealed through the analysis of oral traditions that somehow encompass insects. Indigenous peoples have an intimate knowledge of their biological environment, since they are expert manipulators of processes and ecological relationships, and tend to adopt sustainable management practices. The role that insects play in any economic system is important, although they represent only a small part of total resources. However, due to ethnocentric reasons, since insects are not considered appropriately in other cultures, there has been a tendency to ignore or omit their relevance to other cultures. Or, when mentioned, we have only their indigenous or generic names, making it difficult to know which species they belong to.

Considering the rich biosociodiversity found in Brazil, it could be stated that entomophagy in the country is much underestimated, since nutritious edible insects are abundantly available. We must change the idea that insects can not be included as food items of the human diet (educational campaigns), and we should also think of marketing strategies to launch products based on edible species. Methods for mass production of insects in adequate sanitary conditions should be done in order to not depend on the collection of specimens directly from nature.

Edible insects are one of the renewable resources that are available for sustainable exploration to relieve malnutrition and hunger in the world. Through selecting suitable insects for human consumption, Western populations need to review their eating habits and consider, in the light of current knowledge, the nutritive potential offered by insects, given the large quantity of proteins, fats, vitamins and minerals they present. The discovery of a new dish does more for the happiness of mankind than the discovery of a new star (Boyle 1992).

\section{REFERENCES}

Adamolekum, B., D. W. McCandless, and R. F. Butterworth. 1997. Epidemic of seasonal ataxia in Nigeria following ingestion of the African silkworm Anaphe venata: role of thiamine deficiency? Metabolic Brain Disease 12(4):251-258.

Akinnawo, O. O., M. O. Abatan, and A. O. Ketiku. 2002. Toxicological study on the edible larva of Cirina forda (Westwood). African 
Journal of Biomedical Research 5:43-46.

Allotey, J., and S. Mpuchane. 2003. Utilization of useful insects as food source. African Journal of Food and Agriculture, Nutrition and Development 3(2):112-121.

Allport, S. 2000. The primal feast: Food, sex, foraging, and love. New York: Harmony Books.

Amadi, E. N., O. K. Ogbalu, L. S. Barimalaa, and M. Pius. 2005. Microbiology and nutritional composition of an edible larva (Bunaea alcione Stoll) of the Niger Delta. Journal of Food Safety 25:193-197.

Banjo A. D., O. A. Lawal, O. A. Olubanjo, and O. A. Owolana. 2004. Ethno-zoological knowledge and perception of the value of insects among the Ijebus (south western Nigeria). Global Journal of Pure and Applied Sciences 10(1):1-6.

Banjo, A. D., O. A. Lawal, and E. A. Songonuga. 2006. The nutritional value of fourteen species of edible insects in southwestern Nigeria. African Journal of Biotechnology 5(3):298-301.

Berenbaum, M. R. 1995. Bugs in the system: Insects and their impact on buman affairs. Massachusetts: Addison-Wesley.

Bergier, E. 1941. Peuples entomophages et insectes comestibles: Étude sur les moeurs de l'homme et de l'insecte. Avignon: Imprimerie Rullière Frères.

Blum, M. S. 1994. The limits of entomophagy: a discretionary gourmand in a world of toxic insects. The Food Insects Newsletter 7(1):1, 6-11.

Bodenheimer, F. S. 1951. Insects as buman food. The Hague: W. Junk.

Bordotti, V. 2001. Diversidade da entomofauna utilizada por populacōoes humanas. Variação espacial da composição taxonômica. Master Dissertation, Instituto de Biociências, UNESP, Brazil.

Boyle, R. H. 1992. The joy of cooking in- sects. Audubon 94(5):100-103.

Bristowe, W. S. 1932. Insects and other invertebrates for human consumption in Siam. Transactions of the Entomological Society of London 80:387-404.

Buzzi, Z. J., and R. D. Miyazaki. 1993. Entomologia didática. Curitiba: Editora da UFPR.

Cerritos, R., and Z. Cano Santana. 2008. Harvesting grasshoppers Sphenarium purpurascens in Mexico for human consumption: a comparison with insecticidal control for managing pest outbreaks. Crop Production 27:473-480.

Chakravorty, J., S. Ghosh, and V. B. MeyerRochow. 2011. Practices of entomophagy and entomotherapy by members of the Nyishi and Galo tribes, two ethnic groups of the state of Arunachal Pradesh (North-East India). Journal of Ethnobiology and Ethnomedicine 7:5.

Chen, P. P., S. Wongsiri, T. Jamyanya, T.E. Rinderer, S. Vongsamanode, M. Matsuka, H.A. Sylvester, B.P. Oldroyd. 1998. Honey bees and other edible insects used as human food in Thailand. American Entomologist 41(1): 24-29.

Conconi, J. R. E. 1984. Los insectos como un recurso actual y potencial. In: Memórias del Seminário sobre Alimentación en México. Instituto de Geografía de la UNAM (n.d.):126-139.

Costa Neto, E. M. 2003. Insetos como fontes de proteínas para o homem: valoração de recursos considerados repugnantes. Interciência 28:136-140.

2004. Insetos como recursos alimentares nativos no semi-árido do estado da Bahia, nordeste do Brasil. Zonas Áridas 8:33-40.

2011. Antropoentomofagia: sobre o consumo de insetos, in Antropoentomofagia: insetos na alimentação humana. Edited by $\mathrm{E}$. M. Costa Neto, pp. 17-37. Feira de Santana: UEFS Editora.

Costa Neto, E. M., and J. Ramos-Elorduy. 
2006. Los insectos comestibles de Brasil: etnicidad, diversidad e importancia en la alimentación. Boletín de la Sociedad Entomológica Aragonesa 38:423-442.

Essig, E. O. 1934. The value of insects to the California Indians. Scientific Monthly 38:181-186.

Davey, G. C. L. 1993. Factors influencing self-rated fear to a novel animal. Cognition and Emotion 7(5):461-471.

. 1994. The "disgusting" spider: the role of disease and illness in the perpetuation of fear of spiders. Society and Animals 2(1):17-25.

DeFoliart, G. R. 1989. The human use of insects as food and as animal feed. Bulletin of the Entomological Society of America 35(1):22-35.

1995. Edible insects as minilivestock. The Food Insects Newsletter 8(2):8, 10.

2004. The human of insects as a food resource. A bibliographic progress. Available at: <http://www.food-insects. com/book7_31/Chapter $\% 2006 \% 20 \% 20$ South $\% 20$ America $\% 20$ Brazil.htm>. Accessed on 14 Aug 2004.

.2005. Overview of role of edible insects in preserving biodiversity, in Ecological implications of minilivestock: Potential of insects, rodents, frogs and snails. Edited by M. G. Paoletti, pp. 123-140. Enfield: Science Publishers.

Descola, P. 1998. Estrutura ou sentimento: a relação com o animal na Amazônia. Mana 4(1):23-45.

Diegues, A. C., and R. S. V. Arruda. Editors. 2001. Saberes tradicionais e biodiversidade no Brasil. Brasília: Ministério do Meio Ambiente; São Paulo: USP. (Biodiversidade, 4).

Dufour, D. L. 1987. Insects as food: a case study from the Northwest Amazon. American Anthropologist 89:383-397.

Durst, P. B., and K. Shono. 2010. Edible forest insect: exploring new horizons and traditional practices, in Edible forest insects as food: bumans bite back: Proceedings of the workshop on Asia-Pacific resources and their development. Edited by P. B. Durst, D. V. Johnson, R. N. Leslie, and K. Shono, pp 1-4. Chiang Mai/Thailand: FAO Regional Office Bangkok.

Durst, P. B,. D. V. Johnson, R. N. Leslie, and K. Shono. Editors. 2010. Edible Forest insects as food: bumans bite back: Proceedings of the workshop on Asia-Pacific resources and their development. Chiang Mai/Thailand: FAO Regional Office Bangkok.

El-Hassan, N. M., S. Y. Hamed, A. B. Hassan, M. Eltayeb, and E. E. Babiker. 2008. Nutritional evaluation and physiochemical properties of boiled and fried tree locust. Pakistan Journal of Nutrition 7(2):325-329.

Embrapa. 2000. Os biótopos acridianos e a relação homem-gafanhoto. Available at <http:// www.cnpm.embrapa.br/projects/grshop_ us/36.html> Accessed on 30 Apr. 2000.

Fritzsche, I., and B. Gitsaga. 2002. Das Insekten-Kochbuch: der etwas andere Geschmack. Münster: Natur und Tier.

Gordon, D. G. 1998. The eat-a-bug cookbook. Berkely: Ten Speed Press.

Harris, M. 1999. Bueno para comer: enigmas de alimentación y cultura. Madrid: Alianza.

Hernández-Pacheco, F. 1921. Escena pictórica con representaciones de insectos de época paleolítica. Boletín de la Real Sociedad Española de Historia Natural 5:62-77.

Hogue, C. L. 1987. Cultural entomology. Annual Review of Entomology 32:181-199.

Hölldobler, B., and E. O. Wilson. 1994. Journey to the ants: A story of scientific exploration. Cambridge: Harvard University Press.

Holt, V. M. 1988. Why not eat insects? Kent: Pryor Publications.

ISA.Instituto Socioambiental. 2005. Povos 
indígenas no Brasil. Quadro geral. Available at <http://www. socioambiental.org/ $\mathrm{pib} /$ portugues/quonqua/quadro.asp $>$. Accessed on 31 Oct 2005.

Johnson, D. V. 2010. The contribution of edible forest insects to human nutrition and to forest management, in Edible forest insects as food: humans bite back: Proceedings of the workshop on Asia-Pacific resources and their development. Edited by P. B. Durst, D. V. Johnson, R. N. Leslie, and K. Shono, pp 5-22. Chiang Mai/Thailand: FAO Regional Office Bangkok.

Katz, E. 2011. Prefácio, in Antropoentomofagia: insetos na alimentação humana. Edited by E. M. Costa Neto, pp. 9-16. Feira de Santana: UEFS Editora.

Kellert, S. R. 1993. Values and perceptions of invertebrates. Conservation Biology 7(4):845-853.

Lenko, K., and N. Papavero. 1996. Insetos no folclore. São Paulo: Plêiade/FAPESP.

Linasi, R., and B. Borghetti. 2011. Antropoentomofagia: um estudo sobre as potencialidades dos insetos como alimento no Brasil, in Antropoentomofagia: insetos na alimentação bumana. Edited by E. M. Costa Neto, pp. 55-75. Feira de Santana: UEFS Editora.

Malaisse, F. 1997. Se nourrir en forêt claire. Approche écologique et nutritionnelle. Wageningen: Presses Agronomiques de Gembloux.

Maheu, E. 2011. Onívoros? Limitações e possibilidades do comestível e do palatável diante das fronteiras culturais: o caso dos insetos, in Antropoentomofagia: insetos na alimentação bumana. Edited by E. M. Costa Neto, pp. 39-54. Feira de Santana: UEFS Editora.

Matchett, G., and G. C. L. Davey. 1991. A test of a disease-avoidance model of animal phobias. Behaviour Research and Therapy 29(1):91-94.

Mbata, K. J., E. N. Chidumayo, and C. M. Lwatula. 2002. Traditional regulation of edible caterpillar exploitation in the Kopa area of Mpika district innnorther Zambia. Journal of Insect Conservation 6:115-130.

Menzel, P., and F. D’Alluisio. 1998. Man eating bugs: The art and science of eating insects. Berkeley: Material World Books.

Miller, C. A. 1997. Determinants of the use of insects as human food within the Great Basin. The Food Insects Newsletter 10(1):1-4.

Mpuchane, S., B. A. Gashe, J. Allotey, B. Siame, G. Teferra, and M. Ditlhogo. 2000. Quality deterioration of phane, the edible caterpillar of an emperor moth Imbrasia belina. Food Control 11:453-458.

Myers, N. 1983. Homo insectivorus. Ciência Ilustrada (s.n.): 86-88.

Omotoso, O. T. 2006. Nutritional quality, functional properties and anti-nutrient compositions of the larva of Cirina forda (Westwood) (Lepidoptera: Saturniidae). Journal of Zhejiang University Science B 7(1):51-55.

Pemberton, R. W. 2005. Contemporary use of insects and other arthropods in traditional Korean medicine (hanbang) in South Korea and elsewhere, in Ecological implications of minilivestock: potential of insects, rodents, frogs and snails. Edited by $\mathrm{M}$. G. Paoletti, pp. 459-471. Enfield: Science Publishers.

Pemberton, R. W. 1999. Insects and other arthropods used as drugs in Korean traditional medicine. Journal of Ethnopharmacology 65:207-216.

Pereira, N. 1974. Panorama da alimentaçao indigena: comidas, bebidas e tóxicos na Amazônia brasileira. Rio de Janeiro: Livraria São José.

Pérez, R. M., J. Ramos-Elorduy, G. Yescas, and J. L. Muñoz. 1989. Aislamiento de fenoxazina a partir del insecto Pachilis gigas (Insecta-Hemiptera-Coreidae). Acta Mex. Cienc. Tecnol IV:21-24. 
Petiza, S. 2011. Etnoentomologia Baniwa: estudo dos insetos na concepscão dos povos Baniwa que vivem na cidade de São Gabriel da Cachoeira - Amazonas, Brasil. Master dissertation. Manaus: Instituto ncional de Pesquisas da Amazônia.

Posey, D. A. 1976. Entomological considerations in southeastern aboriginal demography. Ethnohistory 23(2):147-160.

1986. Etnoentomologia de tribos indígenas da Amazônia, in Suma etnológica brasileira: etnobiologia. Edited by D. Ribeiro, Vol. 1, pp. 251-271. Petrópolis: Vozes/FINEP.

1987a. Temas e inquirições em etnoentomologia: algumas sugestões quanto à geração de hipóteses. Boletim do Musen Paraense Emilio Göeldi 3(2):99-134. (Série Antropologia).

1987b. Ethnoentomological survey of Brazilian Indians. Entomology General 12(2/3):191-202.

Ramos-Elorduy, J. 1982. Los insectos como fuente de proteina en el futuro. México, D.F.: Limusa.

1996. Insect consumption as a mean of national identity, in Ethnobiology in human welfare. Edited by S. K. Jain, pp. 9-12. New Delhi: Deep.

1998. Creepy crawly cuisine: The gourmet guide to edible insects. Vermont: Park Street Press.

2000. La etnoentomología actual en México en la alimentación humana, en la medicina tradicional y en la reciclaje y alimentación animal, in Congreso Nacional de Entomología 35, Memórias, pp. 3-46. Acapulco: Sociedad Mexicana de Entomología.

2004. La etnoentomología en la alimentación, la medicina y el reciclaje, in Biodiversidad, taxonomía y biogeografía de artrópodos de México: Hacia una sintesis de su conocimiento. Vol. 4. Edited by J. B. Llorente, J. J. Morrone, O. O. Yañez, and I. F. Vargas, pp. 329-413. México: UNAM.
2006. Threatened edible insects in Hidalgo, Mexico and some measures to preserve them. Journal of Ethnobiology and Ethnomedicine 2:51.

2011. Evolución de la comercialización de insectos comestibles, in Antropoentomofagia: insetos na alimentação humana. Edited by E. M. Costa Neto, pp. 103-122. Feira de Santana: UEFS Editora.

Ramos Eloduy, J., and J. M. Pino Moreno. 1989. Los insectos comestibles del México antiguo. México, D.F.: AGT Editor.

Ramos-Elorduy, J., J. M. Pino Moreno, E. E. Prado, M. Perez, J. L. Otero, and O. L. Guevara. 1997. Nutritional value of edible insects from the state of Oaxaca, Mexico. Journal of Food Composition and Analysis 10: 42-157.

Ramos-Elorduy, J., J. M. Pino Moreno, and S. C. Correa. 1998a. Insectos comestibles del Estado de México y determinación de su valor nutritivo. Annales del Instituto de Biología de la UNAM 69(1):65-104.

Ramos-Elorduy, J., J. J. Muñoz, and J. M. Pino Moreno. 1998b. Determinación de minerales en algunos insectos comestibles de México. Revista de la Sociedad de Química de México 42(1):18-33.

Ramos-Elorduy, J.; I. Landero-Torres, J. Murguía-González, and J. M. Pino Moreno. 2008. Biodiversidad antropoentomofágica de la región de Zongolica, Veracruz, México. Revista de Biología Tropical 56(1):303-316.

Ribeiro, B. G., and T. Kenhíri. 1987. Calendário econômico dos índios Desâna. Ciência Hoje 6(36):26-35.

Rozin, P. 1995. Des goûts et des dégoûts, in Mille et une bouches: Cuisines et identities culturelles. Edited by S. Bessis, pp. 96-105. Paris: Autrement.

Rozin, P., and A. E. Fallon. 1987. A perspective on disgust. Psychological Revien 94:23-41. 
Santos, E. 1957. Histórias, lendas e folclore de nossos bichos. Rio de Janeiro: Cruzeiro.

Schickler, G. 2011. Nutrinsecta: trajetória e metas, in Antropoentomofagia: insetos na alimentação bumana. Edited by E. M. Costa Neto, pp. 93-101. Feira de Santana: UEFS Editora.

Seligman, M. E. P. 1971. Phobias and preparedness. Behavior Therapy 2(3):307-320.

Stone, J. L. 1992. Keeping and breeding butterflies and other exotica: Praying mantis, scorpions, stick insects, leaf insects, locusts, large spiders and leaf-cutter ants. London: Blandford Press.

Sutton, M. Q. 1995. Archaeological aspects of insect use. Journal of Archaeological Method and Theory 2(3):253-298.

van der Merwe, N. J., J. C. Thackeray, J. A. Lee-Thorp, and J. Luyt. 2003. The carbon isotope ecology and diet of Australopithecus africanus at Sterkfontein, South Africa. Journal of Human Evolution 44:581-597.

van Huis, A. 2012. Potential of insects as food and feed in assuring food security. Reviews in Advance 58:563-583.

Ware, J., J. Kumud, I. Burgess, and G. C. L. Davey. 1994. Disease-avoidance model: factor analysis of common animal fears. Behaviour Research and Therapy 32(1):57-63.

Yhoung-Aree, J., and K. Viwatpanich. 2005. Edible insects in the Laos PDR, Myanmar, Thailand, and Vietnam, in Ecological implications of minilivestock: Potential of insects, rodents, frogs and snails. Edited by M. G. Paoletti, pp. 415-440. Enfield: Science Publishers.

Yen, A. L. 2009a. Entomophagy and insect conservation: some thought for digestion. Journal of Insect Conservation 13:667-670.

2009b. Edible insects: Traditional knowledge or western phobia? Entomological Research 39(5):289-298.

Zimian, D., Z. Yonghua, and G. Xiwu. 2005. Medicinal terrestrial arthropods in China, in Ecological implications of minilivestock: Potential of insects, rodents, frogs and snails. Edited by M. G. Paoletti, pp. 481489. Enfield: Science Publishers.

Recebido em 10/02/2013.

Aprovado em 11/06/2013. 